Egyptian Journal of Aquatic Biology \& Fisheries

Zoology Department, Faculty of Science,

Ain Shams University, Cairo, Egypt.

ISSN $1110-6131$

Vol. 25 ( 5): 373 - 391 (2021)

www.ejabf.journals.ekb.eg

\title{
Length-weight, condition factors, age, and growth of Scomber japonicus (Houttuyn, 1782) from the Egyptian Mediterranean Sea
}

\author{
Mohamed F. Abdel Fattah ${ }^{1}$, Alaa A. K. El-Haweet ${ }^{2}$, \\ Mahmoud M. S. Farrag ${ }^{1 *}$, Rania F. Ismail ${ }^{3}$ and Alaa G.M. Osman ${ }^{1}$ \\ ${ }^{1}$ Faculty of Science, Al-Azhar University (Assiut Branch), Egypt. \\ ${ }^{2}$ College of Fisheries, Technology, and Aquaculture. Arab Academy for Science, \\ Technology and Maritime Transportation, Egypt. \\ ${ }^{3}$ National Institute of Oceanography and Fisheries (NIOF), Egypt \\ *Corresponding Author: m mahrousfarrag@yahoo.com;farrag@igb-berlin.de
}

\section{ARTICLE INFO}

Article History:

Received: Aug. 15, 2021

Accepted: Oct. 17, 2021

Online: Oct. 22, 2021

Keywords:

Scomber japonicus,

age,

growth,

length-weight, condition factors,

Mediterranean Sea,

Egypt.

\section{ABSTRACT}

Length-weight, condition factors, age, and growth of Scomber japonicus were investigated. The specimens were collected monthly from Alexandria landing centers during 2017 and caught using night purse seine ranging from 12.9 to $34.4(\mathrm{TL})$ (average, $21.00 \pm 4.1) \mathrm{cm}$ and from 15.10 to 391.49 (TW) (average, $92.81 \pm 59.17$ ) g. The exponent "b" of the length-weight relationships were " $>3$ " for females $(b=3.24)$, males $(b=$ $3.25)$, and all samples $(b=3.15)$, reflecting the positive allometric mode of growth. Moreover, the positive allometric mode of growth was observed for the relationship between forked length (FL) and standard length (SL) with weight. The annual average of absolute condition was $0.89 \pm 0.06$, with the highest value during April $(0.96 \pm 0.05)$. The annual average relative condition was $1.01 \pm 0.06$, with the highest value $(1.10 \pm 0.10)$ during August. The absolute condition (Kc) increased with the increasing length. However, the relative condition showed an inverse trend. The age of S. japonicus was determined using lengthfrequency analysis giving five age groups at mean lengths of 14.09, $19.29,23.82,28.25$, and $31.76 \mathrm{~cm}$ for the $1^{\text {st }}, 2^{\text {nd }}, 3^{\text {rd }}, 4^{\text {th }}$, and $5^{\text {th }}$ age groups, respectively. The third age group (III) was the most frequent one $(38.89 \%)$. The estimated growth parameters were $L \infty$ of $38.11 \mathrm{~cm}$; $\mathrm{W} \infty, 534.74$; K, 0.33 year-1; growth performance $(\varnothing), 2.68$; and t-max, 8.89 years. In conclusion, the present data reflected a good stock status with the suitability of living habitats. Further continuous monitoring is recommended for better fishery management and conservation.

\section{INTRODUCTION}

The Chub mackerel Scomber japonicus (Houttuyn, 1782) is a famous species of the family Scombridae living between 0 and $300 \mathrm{~m}$ depth primarily as a coastal pelagic species. However, they are usually 
abundant at within 50-200 $\mathrm{m}$ in subtropical waters of approximately $10^{\circ} \mathrm{C}-$ $27^{\circ} \mathrm{C}$ (Castro, 2000). Chub mackerel is widely distributed over the continental shelves of the tropical and subtropical regions of the Pacific, Indian, and Atlantic Oceans and adjacent Seas (Collette and Naunen, 1983). This species usually ranked the important commercial importance in its habitat (FAO, 2010). In Egypt, it represented an important fishery in both the Red and Mediterranean Seas (GFARD, 2018). Chub mackerel forms one of the primary and commercial fish species in purse seine fishing operations in the Red Sea and Gulf of Suez (Mehanna, 2002, 2004) and the Mediterranean Sea of Egypt (Faltas, 1983; Akel, 2009 and Farrag et al., 2014). Hence, detailed and continuous information should be obtained for effective fisheries management.

Fish age and growth are also necessary to evaluate the biological aspects, such as productivity, yield per recruit, prey availability, habitat suitability, and even feeding kinematics (Campana, 2001; Robinson \& Motta, 2002 and Farrag et al., 2014). An item of length-weight relationship is among the growth studying items needed to appreciate the suitability of the fish environment and play an important role in fishery management (Richter et al., 2000). Other factors such as the environmental conditions required to describe the plumpness or well-being of the fish are based on the hypothesis that heavier fish of a particular length is a better physiological condition (Bagenal and Tesch, 1978). Condition factors are also a useful index to monitor the feeding intensity, age, and growth rates in the fish (Ndimele et al., 2010). Although the importance of these commercially available fish has been known, a few studies were conducted for S. japonicus in the Mediterranean Sea, Egypt (Faltas \& Rizkalla, 1995; Rizkalla \& Faltas, 1997 and Rizkalla, 1998) Moreover, the recent study of El-Aiatt and Shalloof, (2020) was conducted on the another species under the same genus of Scomber known as $S$. scombrus. Therefore, this study aimed to explore the age and growth of the common chub mackerel $S$. japonicus from the Egyptian Mediterranean Waters to support its conservation and further management. 


\section{MATERIALS AND METHODS}

\section{Study area and sampling}

The total length (TL) of 511 specimens ranged from 12.9 to 34.4 cm of "chub mackerel" S. japonicus (Fig. 1), which was collected monthly from Alexandria landing centers in 2017. The specimens were randomly obtained from the catch of the fishing vessels (purse-seine using light), which operated at a depth from 40 to $60 \mathrm{~m}$ in the Egyptian Mediterranean water-off Alexandria (Fig. 1). At the NIOF laboratory Alexandria branch, the specimens were dissected and sorted based on sex and maturity stages of each fish, and then the TL, standard length (SL), and forked length (FL) of each fish were measured to the nearest centimeter $(\mathrm{cm})$, while the total weight (TW) of each fish was weighed to the nearest gram.

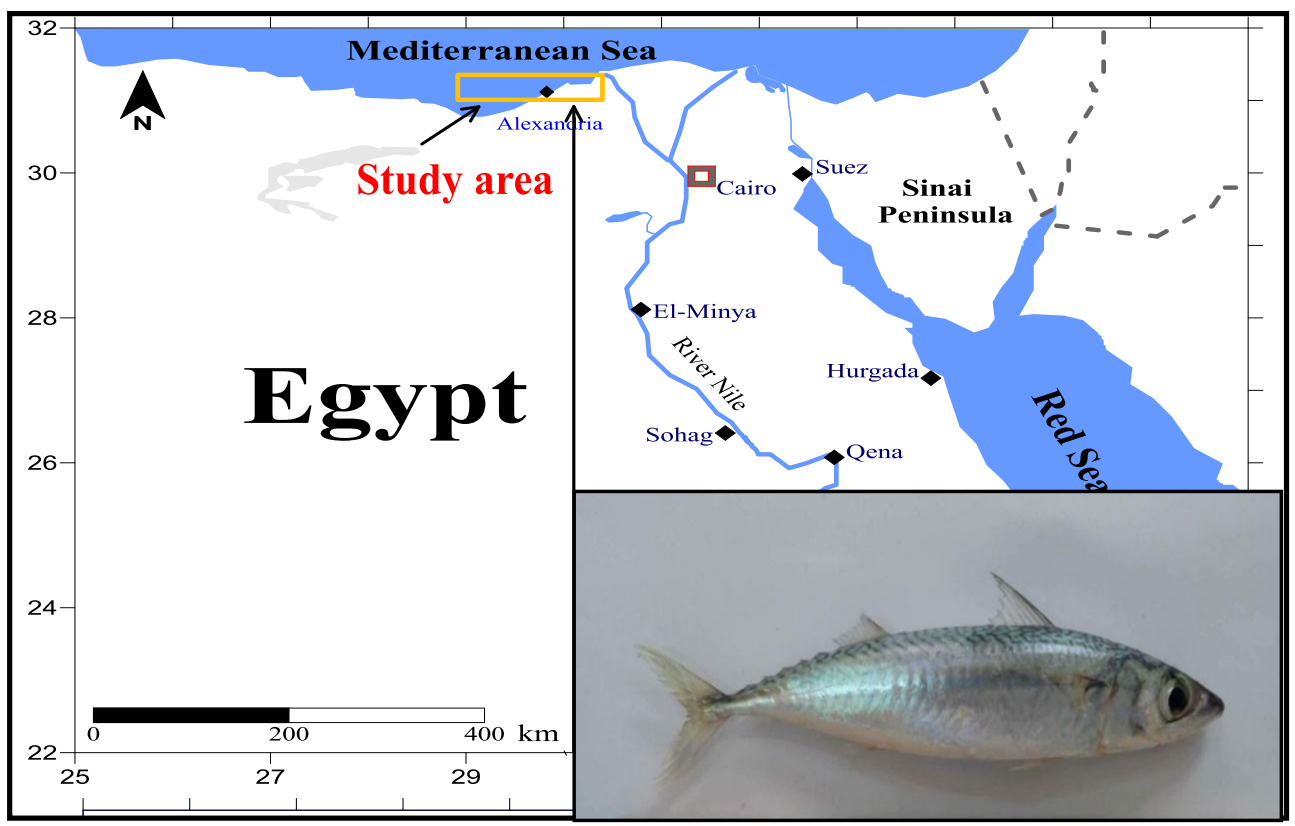

Figure 1. Study area at Alexandria coast, Mediterranean Sea, Egypt, with the photo of chub mackerel, S. japonicus.

\section{Length-weight relationship and condition factors}

The length-weight relationship was calculated by applying an exponential regression equation $\mathrm{W}=\mathrm{a} \mathrm{L}^{\mathrm{b}}$, where $\mathrm{W}$ is the $\mathrm{TW}(\mathrm{g}), \mathrm{L}$ is the TL $(\mathrm{cm})$, a and b are constants (Ricker, 1973). 
The absolute condition factor $(\mathrm{Kc})$ was estimated based on the cube law (Bagenal and Tesch, 1978) as $\mathrm{K}=100 \times \mathrm{W} \backslash \mathrm{L}^{3}$. The relative condition (Kn) was determined as $\mathrm{Kn}=\mathrm{W} / \mathrm{W}^{`}$ (Le Cren, 1951) where $\mathrm{W}$ is the TW (g) and $\mathrm{W}^{-}$is the calculated weight, which was estimated from the length-weight relationship.

\section{Age determination}

Age was determined by analyzing the length-frequency data of 511 specimens using the standard statistical method of Bhattacharya (1967) in the subroutine of the Fi-SAT software (Gayanilo et al., 1997), which allow the conversion of length-frequency data into age groups.

\section{Growth parameters}

The Von Bertalanffy growth parameters (VBGF) including the asymptotic or maximum size of the fish were used to estimate $\mathrm{L} \infty$ and growth coefficient $(\mathrm{K})$. The growth performance index $\Phi$ ' was estimated according to $\Phi=\log (\mathrm{k})+2 \log (\mathrm{L} \infty)$ (Pauly and Munro, 1984). The potential longevity of age $\left(t_{\max }\right)$ was estimated $t_{\max }=3 / \mathrm{k}+\mathrm{t}_{\mathrm{o}}$ according to Pauly (1983), where $t_{0}=-a / b$. The presented data were statistically analsyzed using Microsoft Excel, and t-tests were conducted in Statistica software (2007).

\section{RESULTS}

\section{Length-weight relationship}

The length of all samples used for this calculated item ranged from 12.9 to 34.4 (average, $21.00 \pm 4.1$ ) $\mathrm{cm}$ (TL) and from 15.10 to 391.49 (average, $92.81 \pm 59.17) \mathrm{g}(\mathrm{TW})$. For males, the size varied from 18.6 to 32.6 (average, 25.00 ) $\mathrm{cm}$, whereas for females, the size varied from 18.6 to 34.4 (average, 23.8) cm. The relationship between length and weight of $S$. japonicus from Alexandria was estimated using different length measures, including the TL, SL, and FL. For the TL in $\mathrm{cm}$ and TW in $\mathrm{g}$, the results illustrated that the exponent $b$ was $>$ " 3 " for males $(b=3.25)$, females $(b=$ $3.24)$, and all samples $(b=3.15)$, reflecting the positive allometric mode of growth for all categories. A similar trend of positive allometric mode of growth was observed while using FL or SL instead of TL with weight (Table 1). 


\section{Condition factors (Kc and Kn).}

Both the absolute condition factor (kc) and relative condition $(\mathrm{Kn})$ were analyzed for all samples. According to the month (Figure, 2), both condition factors display a fluctuation during the year. For the absolute condition, the highest value was recorded during April $(0.96 \pm 0.05)$, whereas the lower absolute condition was recorded during June $(0.80 \pm 0.07)$. The annual average was $0.892 \pm 0.06$. The $\mathrm{kn}$, recorded in the annual average, was $1.01 \pm 0.06$ with the highest value $(1.10 \pm 0.10)$ during August, whereas the lowest one $(0.93 \pm 0.07)$ was during February.

Table 1. Length-weight relationships for S. japonicus. ((TL/TW, FL/TW, and SL/TW)

\begin{tabular}{|c|c|c|c|c|c|c|c|c|c|}
\hline \multicolumn{10}{|c|}{ Length-weight relationships for $S$. japonicus $\left(\mathrm{W}=\mathbf{a} \mathbf{L}^{\mathbf{b}}\right)$} \\
\hline \multirow{2}{*}{ Sex } & \multirow{2}{*}{$\mathbf{N}$} & \multicolumn{2}{|c|}{$\begin{array}{l}\text { Total length } \\
\text { (TL cm) }\end{array}$} & \multicolumn{2}{|c|}{ Total weight (g) } & \multicolumn{4}{|c|}{ Parameters and mode of growth } \\
\hline & & Min. & Max. & Min. & Max. & a & b & $\mathbf{R}^{2}$ & Allometry \\
\hline Females & 239 & 18.6 & 34.4 & 54.97 & 391.49 & 0.0041 & 3.24 & 0.96 & Positive \\
\hline Males & 200 & 18.6 & 32.6 & 56.02 & 342.22 & 0.004 & 3.25 & 0.97 & Positive \\
\hline All samples & 511 & 12.9 & 34.4 & 15.1 & 391.49 & 0.0056 & 3.14 & 0.98 & Positive \\
\hline \multirow[t]{2}{*}{ Sex } & \multirow[t]{2}{*}{$\mathbf{N}$} & \multicolumn{2}{|c|}{$\begin{array}{l}\text { Fork length } \\
(\mathrm{FL} \mathrm{cm})\end{array}$} & \multicolumn{2}{|c|}{ Total weight (g) } & & & & --------- \\
\hline & & Min. & Max. & Min. & Max. & $\mathbf{a}$ & b & $\mathbf{R}^{2}$ & Allometry \\
\hline Females & 239 & 17 & 31.5 & 54.97 & 391.49 & 0.006 & 3.21 & 0.98 & Positive \\
\hline Males & 200 & 17 & 29.8 & 56.02 & 342.22 & 0.006 & 3.2 & 0.98 & Positive \\
\hline All samples & 511 & 11.8 & 31.5 & 15.1 & 391.49 & 0.006 & 3.22 & 0.99 & Positive \\
\hline \multirow{2}{*}{ Sex } & \multirow[t]{2}{*}{$\mathbf{N}$} & \multicolumn{2}{|c|}{$\begin{array}{l}\text { Standard length } \\
(\text { SL cm) }\end{array}$} & \multicolumn{2}{|c|}{ Total weight (g) } & & & & ----------. \\
\hline & & Min. & Max. & Min. & Max. & $\mathbf{a}$ & b & $\mathbf{R}^{2}$ & Allometry \\
\hline Females & 239 & 15.7 & 29.4 & 54.97 & 391.49 & 0.006 & 3.27 & 0.96 & Positive \\
\hline Males & 200 & 15.7 & 27.4 & 56.02 & 342.22 & 0.005 & 3.34 & 0.97 & Positive \\
\hline All samples & 511 & 10.9 & 29.4 & 15.1 & 391.49 & 0.008 & 3.19 & 0.98 & Positive \\
\hline
\end{tabular}

According to length bases (Figure 3), the absolute condition $(\mathrm{Kc})$ increased with increased length. The lowest condition $(0.84 \pm$ 0.08 ) was recorded at the lowest length group (L 12.0-17.0 cm), whereas the largest condition was recorded as $0.95 \pm 0.05$ at the largest length groups (L 28.1-34.4 cm). The relative condition showed 
the highest conditions at length groups (L 17.1-21.0 cm), which decreased as the length groups increased in an inverse trend.

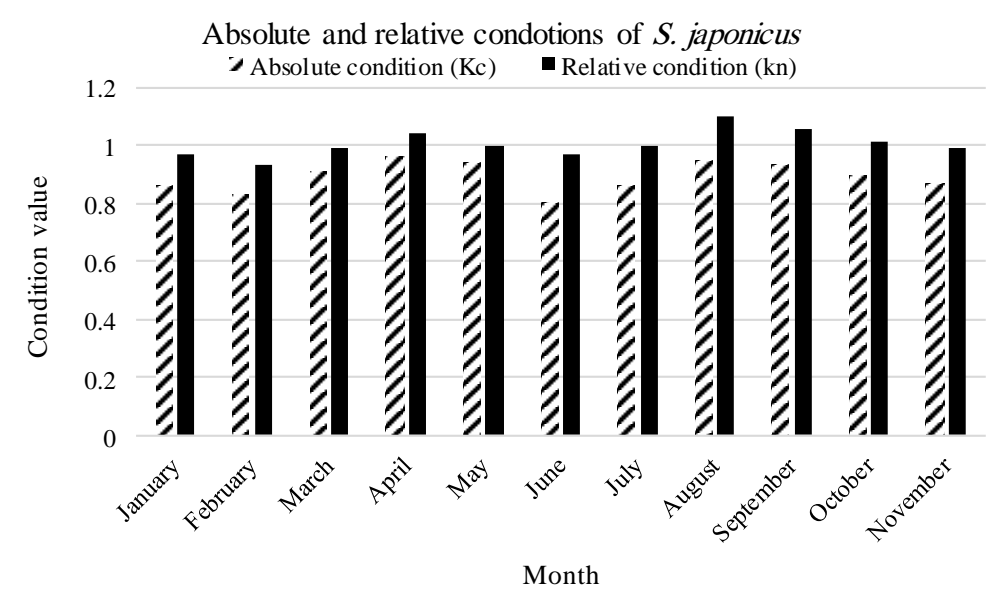

Figure 2. Monthly mean variations of absolute condition $(\mathrm{Kc})$ and relative condition (Kn) for all samples of S. japonicus.

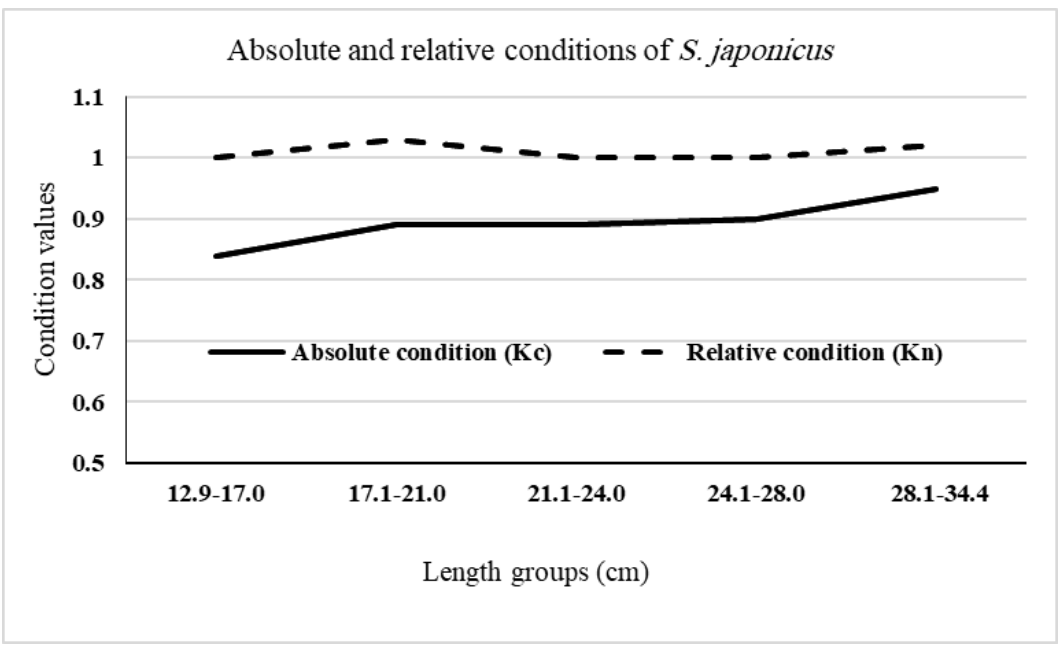

Figure 3. Variations in means of absolute condition $(\mathrm{Kc})$ and relative condition (Kn) with length groups for all samples of S. japonicus.

\section{Age determination}

The age of S. japonicus was determined using length-frequency analysis for all samples showing five age groups (Figure 4). The third age group (III) most frequently constituted $38.89 \%$, followed by the second age group (II) with $33.33 \%$. The estimated lengths of each age group are presented in Table 2, with the mean lengths of 14.09, 19.29, 
$23.82,28.25$, and $31.76 \mathrm{~cm}$ for the $1^{\text {st }}, 2^{\text {nd }}, 3^{\text {rd }}, 4^{\text {th }}$, and $5^{\text {th }}$ groups, respectively.

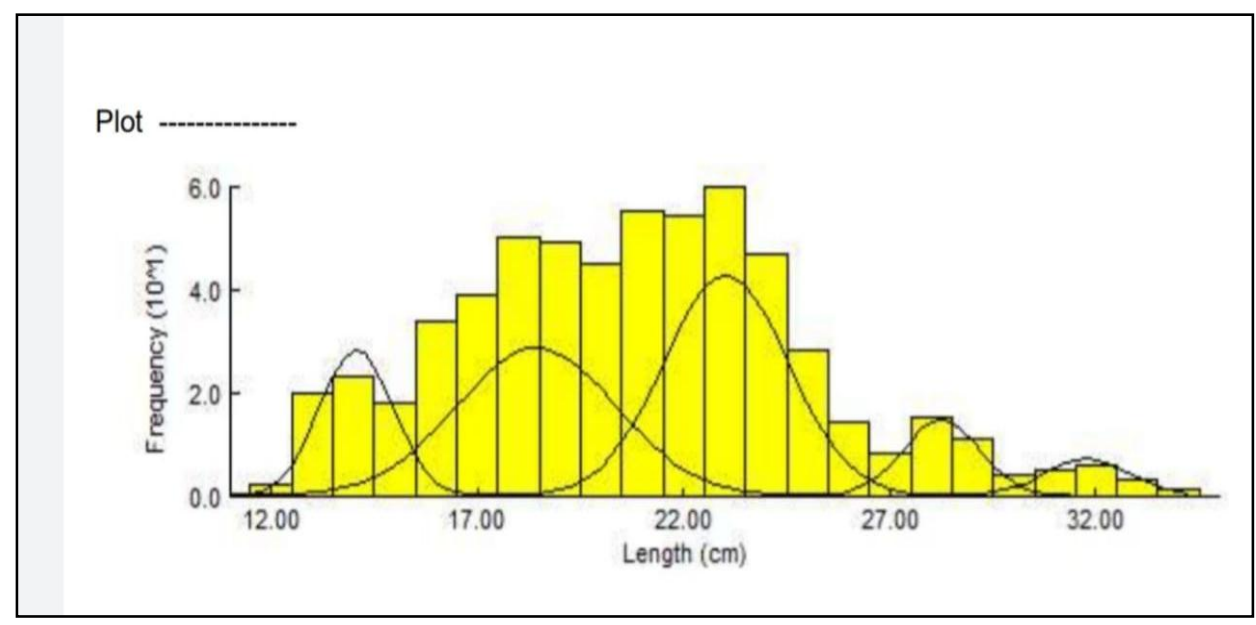

Figure 4. Length frequency distribution for all samples of $S$. japonicus from the Egyptian Mediterranean waters using the Bhattacharya method.

\section{Growth in length and weight at age and growth parameters}

Growth in lengths and weights of $S$. japonicus are shown in Table 2 and presented in Figure 5. The highest increment in length was observed at the end of the first age group, and then the annual increment gradually decreased with the increase toward the $5^{\text {th }}$ age group. The increase in weight acquired the lowest values during the first year of life of 23.28, and the annual increment increased with the increasing age until it reached the maximum weight in the 5th age group $(301.17 \mathrm{~g})$. The calculated weights for each age group were estimated to be $23.28,62.62,121.70,208.26$, and $301.17 \mathrm{~g}$ for the $1^{\text {st }}, 2^{\text {nd }}, 3^{\text {rd }}, 4^{\text {th }}$, and $5^{\text {th }}$ years of life, respectively (Table 2 and Figure $5 \mathrm{a}, \mathrm{b}$ ).

Table 2. Estimated lengths and annual increment of growth in length and weight for all samples of S. japonicus from the Egyptian Mediterranean water.

\begin{tabular}{cccccc}
\hline $\begin{array}{c}\text { Age } \\
\text { group }\end{array}$ & $\%$ & $\begin{array}{c}\text { Estimated } \\
\text { Length }\end{array}$ & $\begin{array}{c}\text { Increment } \\
(\mathbf{c m})\end{array}$ & $\begin{array}{c}\text { Estimated } \\
\text { weight }\end{array}$ & $\begin{array}{c}\text { Increment } \\
\text { (gm) }\end{array}$ \\
\hline I & 15.22 & 14.09 & 14.09 & 23.28 & 23.28 \\
\hline II & 33.33 & 19.29 & 5.2 & 62.62 & 39.34 \\
\hline III & 38.89 & 23.82 & 4.53 & 121.70 & 59.07 \\
\hline IV & 9.18 & 28.25 & 4.43 & 208.26 & 86.56 \\
\hline V & 3.38 & 31.76 & 3.51 & 301.17 & 92.91 \\
\hline
\end{tabular}



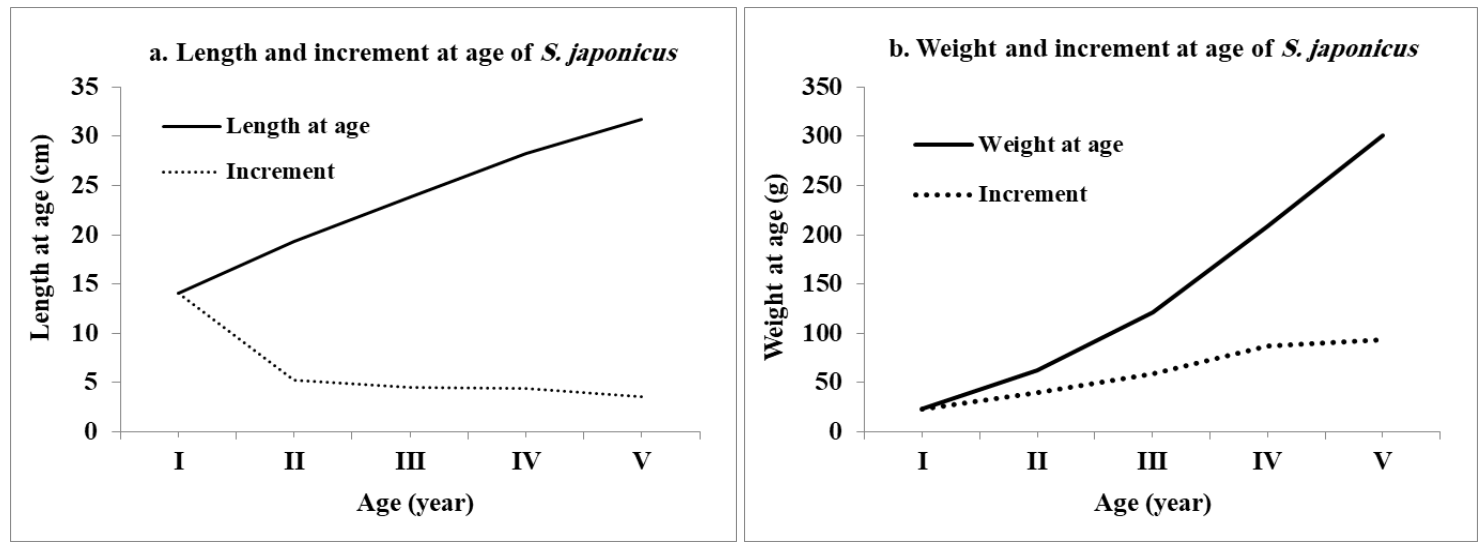

Figure 5 a, b. Estimated lengths and annual increment of growth in length and weight for all samples of $S$. japonicus (a: lengths, b: weights).

To confirm the results of calculated lengths and weights, the growth model was fitted based on the results of length-frequency methods. The calculated and estimated values of lengths and weights from all samples are shown in Table 3, and their graphical presentations are shown in Figure 6 a, b. A close agreement and obvious confirmation between the estimated and calculated lengths and weights particularly after the second year of life were observed. The growth model parameters of the Bertalanffy growth model $(\mathrm{L} \infty, \mathrm{W} \infty$, and $\mathrm{K}$ ) were estimated as $\mathrm{L} \infty=38.11 \mathrm{~cm} ; \mathrm{W} \infty=534.74$; and $\mathrm{K}=0.33$ at year 1 . The growth performance index $(\varnothing)$ of $S$. japonicus was found to be 2.68 for all samples derived using the Bhattacharya methods. The longevity of age (T max) was 8.89 years.

Table 3. Estimated and calculated lengths at the age of all samples of $S$. japonicus from the Egyptian Mediterranean water.

\begin{tabular}{ccccc}
\hline \multirow{2}{*}{ Age } & \multicolumn{2}{c}{ Growth in length } & \multicolumn{2}{c}{ Growth in weight } \\
\cline { 2 - 5 } & L.F & VBGL & L.F & VBGL \\
\hline I & 14.09 & 12.46 & 23.28 & 20.88 \\
\hline II & 19.29 & 19.67 & 62.62 & 78.51 \\
\hline III & 23.82 & 24.85 & 121.7 & 154.73 \\
\hline IV & 28.25 & 28.57 & 208.26 & 232.04 \\
\hline V & 31.76 & 31.25 & 301.17 & 300.91 \\
\hline
\end{tabular}



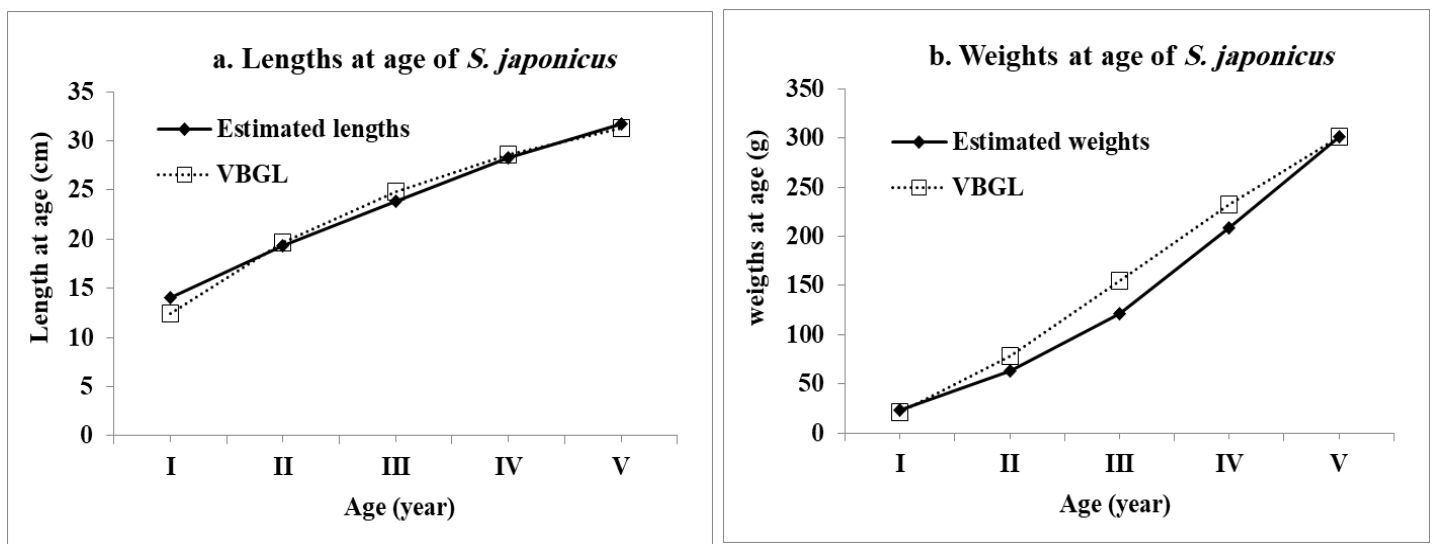

Figure 6, a, b. Estimated and calculated lengths at the age of all samples of $S$. japonicus (a: lengths, b: weights).

\section{DISCUSSION}

Growth is the most important characteristic feature and specific for each fish species. Fish growth is also necessary to evaluate several other biological aspects (Campana, 2001 and Robinson \& Motta, 2002). For applied ichthyological studies, the length-weight relationship is an important parameter in estimating the population growth mode through its value of the slope "b" (Le Cren 1951). The present value of (b) was higher than "3," giving a positive allometric model of growth for males, females, and all samples. Different results of $S$. japonicus from several areas are shown in Table 4. The present exponent "b" was almost similar to those calculated by Rizkall (1998), Santos et al. (2002), Mendes et al. (2004), Sinovčić et al. (2004), Karakulak et al. (2006), Bayhan (2007), İşmen et al. (2007), Gang et al. (2008), Hwang et al. (2008), Vasconcelos et al. (2011), Cengiz (2012), and Jurado-Ruzafa et al. (2017). As it disagreed with those of Özaydın and Taşkavak (2006), Allaya et al. (2013), and Daley (2018), the b-value of $<3$ was considered a negative allometric growth. These differences may be due to variations in habitats, biological, environmental conditions, and geographical variation.

Condition factor $(\mathrm{k})$ is an indicator of the well-being degree and relative robustness of the fish population, which can vary in length, weight, season, and habitat for the same species (Lagler, 1956). The present annual average absolute $(0.89 \pm 0.06)$ and relative condition $(1.01 \pm 0.06)$ were noticed to be around " 1 " as indications for suitable conditions for the 
species growing in the Egyptian Mediterranean waters. The present results disagreed with those of Ghailen et al. (2010), Allaya et al. (2013), and Bal \& Türker (2019) for absolute conditions (Table 5). The authors in this study reported values higher than the present values. The relative conditions showed the same decreasing trend during the spawning season with a higher value than absolute conditions. The relative conditions were in agreement with those reported by Langøy et al. (2012) and JuradoRuzafa et al. (2016). Differences between two indices (absolute and relative) are known in several species. Moreover, differences between values for the same index may be attributed to varied habitats and physiological status and could be influenced by certain extrinsic factors, such as temperature and photoperiod changes (Samat et al., 2008). Regarding the fluctuation in conditions during the spawning period, the decline in the present work may correlate with the requirements and energy release through spawning without the need for power to the livers. The present findings during spawning disagreed with those of Rizkalla (1998) for the same species at the same habitats, where he reported the minimum condition in August following the end of the spawning season. This difference may be due to different length range used where this study used a wider length range including mature and immature specimens, which played a role in increasing/decreasing the condition during spawning.

Based on the length, the absolute condition increased as the length increased, reflecting the health status of fish following their requirements of fast movement and spawning activity for these large length groups. The relative condition is another indicator of the well-being of species and comparative indices between the same species from different habitats. According to Le-Cren (1951), the values equal to/or greater than "1" reflect good growth conditions. In this study, the values of the mean relative conditions were approximately equal to " 1 " for all samples, indicating that this species presented good growth mode and condition in its habitats. Moreover, the relative condition illustrated no obvious trend at a certain season for all individuals, indicating good fitness for the year. The study on the growth pattern of S. japonicus indicated that their highest increment in length was achieved at the end of the first year of life, after which the annual increment decreased gradually as the age increase until it reached its minimum growth at the end of the $5^{\text {th }}$ year of life. The poor growth rate in length after the first year of life may be associated with the 
onset of maturity, which often causes discontinuation of the growth curve (Beverton and Holt, 1957). The growth performance index is used to compare the growth rate of fish species with other species (Pauly and Munro, 1984). Table 4 shows the parameters of $S$. japonicus from different localities. Such differences may be due to different habitats, methods used length range, and number of specimens. The growth performance index $(\varnothing)$ of 2.68 was higher than some previous studies (Aguayo \& Steffens,1986; Kiparissis et al., 2000 and Cengiz 2012), but lower than others (Tuggac, 1957; Mendo, 1984; Perrotta, 1992, Lorenzo et al., 1995, Perrotta et al., 2005, Gang et al., 2008 and Samuel et al., 2016). Differences in habitats were correlated with increasing age at the high growth performance shown in the table, whereas the present index and others with lower values were slightly similar to the same/lower age groups.

Table 4. Some available studies on length-weight relationship and length range of $S$. japonicus from different localities.

\begin{tabular}{|c|c|c|c|c|c|c|c|c|c|c|c|c|}
\hline References & $\begin{array}{c}\text { Locality and } \\
\text { Sampling Gears } \\
\end{array}$ & $\operatorname{Ages}(\mathbf{y})$ & Sex & LT & $\mathbf{L}_{\min }$ & $\mathbf{L}_{\max }$ & b & $\mathbf{r}^{2}$ & $\mathbf{L} \infty$ & $\mathbf{k}$ & $\mathbf{t}_{0}$ & $\Phi$ \\
\hline Tuggac (1957) & Marmara Sea & $\begin{array}{c}1-7 \\
\text { (Otolith) } \\
\end{array}$ & $\Sigma$ & FL & - & - & - & - & 33 & 0.47 & - & 2.71 \\
\hline $\begin{array}{l}\text { Krivospitchenko } \\
\text { (1979) }\end{array}$ & Morocco & - & $\Sigma$ & - & - & - & - & - & 44.1 & 0.32 & -0.83 & 2.8 \\
\hline $\begin{array}{l}\text { Martins and } \\
\text { Serrano-Gordo } \\
(1984)\end{array}$ & Morocco & - & $\Sigma$ & - & - & - & - & - & 51.2 & 0.2 & -1.56 & 2.72 \\
\hline Mendo (1984) & Peru & $\begin{array}{c}1-7 \\
\text { (Otolith) }\end{array}$ & $\Sigma$ & FL & - & - & - & - & 40.6 & 0.41 & -0.05 & 2.83 \\
\hline $\begin{array}{c}\text { Aguayo and } \\
\text { Steffens (1986) }\end{array}$ & North of Chile & $\begin{array}{c}1-7 \\
\text { (Otolith) }\end{array}$ & $\Sigma$ & FL & - & - & - & - & 44.3 & 0.16 & -1.54 & 2.5 \\
\hline Perrotta (1992) & Argentine Sea & $\begin{array}{c}0-10 \\
\text { (Otolith) }\end{array}$ & $\Sigma$ & TL & - & - & - & - & 46 & 0.28 & -1.54 & 2.77 \\
\hline $\begin{array}{c}\text { Lorenzo et al. } \\
\text { (1995) }\end{array}$ & Canary Islands & $\begin{array}{c}1-13 \\
\text { (Otolith) }\end{array}$ & $\Sigma$ & - & - & - & - & - & 49.2 & 0.21 & -1.4 & 2.71 \\
\hline Rizkall (1998) & $\begin{array}{c}\text { Alwxandria, } \\
\text { Medit. Sea, Egypt }\end{array}$ & $\begin{array}{c}1-4 \\
\text { (Vertebrae) }\end{array}$ & $\Sigma$ & TL & 26 & 34 & $\begin{array}{c}\hat{0} \\
2.73 \\
9 \\
.086 \\
\end{array}$ & & 39.42 & & & \\
\hline \multirow{2}{*}{$\begin{array}{l}\text { Kiparissis et al. } \\
\quad(2000)\end{array}$} & \multirow[b]{2}{*}{ Hellenic Seas } & & $\Sigma$ & - & - & - & - & - & 47.6 & 0.15 & -2.18 & 2.53 \\
\hline & & - & $\frac{p}{d}$ & $\begin{array}{l}- \\
-\end{array}$ & - & $\begin{array}{l}- \\
-\end{array}$ & $\begin{array}{l}- \\
-\end{array}$ & - & $\begin{array}{l}34.5 \\
46.4\end{array}$ & $\begin{array}{c}0.3 \\
0.16\end{array}$ & $\begin{array}{l}-1.53 \\
-1.88\end{array}$ & $\frac{2.55}{2.54}$ \\
\hline $\begin{array}{l}\text { Santos et al. } \\
\quad(2002)\end{array}$ & $\begin{array}{l}\text { Algarve coast } \\
\text { (southern } \\
\text { Portugal) - by } \\
\text { all gears Gill } \\
\text { net-Longline- } \\
\text { Pound net } \\
\text { Trammel net- } \\
\text { Trap-Trawl }\end{array}$ & - & $\Sigma$ & $\mathrm{TL}$ & 15.1 & 47.2 & 3.41 & 0.98 & - & - & - & - \\
\hline
\end{tabular}




\begin{tabular}{|c|c|c|c|c|c|c|c|c|c|c|c|c|}
\hline $\begin{array}{l}\text { Mendes et al. } \\
\quad \text { (2004) }\end{array}$ & $\begin{array}{c}\text { Portuguese } \\
\text { west coast- by } \\
\text { Gill net- } \\
\text { Trammel net } \\
\end{array}$ & - & $\Sigma$ & $\mathrm{TL}$ & 19.5 & 46.4 & 3.44 & 0.96 & - & - & - & - \\
\hline \multirow{3}{*}{$\begin{array}{l}\text { Sinovčić et al. } \\
\text { (2004) }\end{array}$} & \multirow{3}{*}{$\begin{array}{l}\text { Adriatic Sea } \\
\text { (Croatia)- by } \\
\text { Beach seine- } \\
\text { Purse seine }\end{array}$} & \multirow{3}{*}{-} & $\Sigma$ & - & 19.6 & 38.8 & 3.14 & 0.91 & - & - & - & - \\
\hline & & & q & - & 20.1 & 38.2 & 3 & 0.82 & - & - & - & - \\
\hline & & & 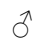 & - & 19.6 & 38.4 & 3.25 & 0.9 & - & - & - & - \\
\hline \multirow{2}{*}{$\begin{array}{l}\text { Perrotta et al. } \\
\quad(2005)\end{array}$} & $\begin{array}{c}\mathrm{NE} \\
\text { Mediterranean } \\
\end{array}$ & $\begin{array}{c}0-9 \\
\text { (Otolith) } \\
\end{array}$ & $\Sigma$ & $\mathrm{TL}$ & 11 & 39 & - & - & - & - & - & - \\
\hline & SW Atlantic & $\begin{array}{c}0-7 \\
\text { (Otolith) }\end{array}$ & $\Sigma$ & $\mathrm{TL}$ & 14 & 45 & - & - & 44.2 & 0.32 & 1.38 & 2.8 \\
\hline $\begin{array}{c}\text { Karakulak et al. } \\
\text { (2006) }\end{array}$ & $\begin{array}{l}\text { Gökceada } \\
\text { Island by } \\
\text { Gill net- } \\
\text { Trammel net }\end{array}$ & - & $\Sigma$ & $\mathrm{TL}$ & 18.1 & 31.2 & 3.1 & 0.97 & - & - & - & - \\
\hline $\begin{array}{c}\text { Özaydın and } \\
\text { Taşkavak } \\
(2006)\end{array}$ & $\begin{array}{l}\text { Izmir Bay by } \\
\text { Beach seine- } \\
\text { Bottom trawl } \\
\text { Gill net- } \\
\text { Trammel net }\end{array}$ & - & $\Sigma$ & FL & 12.5 & 26 & 2.94 & 0.98 & - & - & - & - \\
\hline \multirow{3}{*}{ Bayhan (2007) } & \multirow{3}{*}{$\begin{array}{l}\text { Izmir Bay } \\
\text { Purse seine }\end{array}$} & \multirow{3}{*}{$\begin{array}{l}1-4 \Sigma \\
\text { (Otolith) }\end{array}$} & $\Sigma$ & FL & 12.5 & 27.2 & 3.4 & 0.98 & 29.8 & 0.2 & -0.36 & 2.25 \\
\hline & & & 9 & FL & 13 & 27.2 & 3.41 & 0.97 & 27.1 & 0.26 & -0.48 & 2.28 \\
\hline & & & $\sigma^{1}$ & FL & 12.5 & 26.2 & 3.39 & 0.96 & 29.6 & 0.23 & -0.39 & 2.3 \\
\hline $\begin{array}{l}\text { İşmen } \text { et al. } \\
\text { (2007) }\end{array}$ & $\begin{array}{l}\text { Saros Bay by } \\
\text { Bottom trawl }\end{array}$ & - & $\Sigma$ & $\mathrm{TL}$ & 12.2 & 22 & 3.52 & 0.97 & - & - & - & - \\
\hline $\begin{array}{c}\text { Gang et al. } \\
(2008)\end{array}$ & $\begin{array}{l}\text { East Chine- } \\
\text { Yellow Sea }\end{array}$ & - & $\Sigma$ & FL & 21.5 & 41.1 & 3.2 & 0.99 & 40.4 & 0.49 & -0.9 & 2.9 \\
\hline $\begin{array}{l}\text { Hwag et al. } \\
\quad(2008)\end{array}$ & $\begin{array}{c}\text { Korea } \\
\text { By } \\
\text { Purse seine }\end{array}$ & - & $\Sigma$ & FL & - & - & 3.69 & 0.97 & - & - & - & - \\
\hline $\begin{array}{l}\text { Vasconcelos et } \\
\text { al.(2011) }\end{array}$ & $\begin{array}{c}\text { NE Atlantic } \\
\text { By } \\
\text { Purse-seine }\end{array}$ & $\begin{array}{c}0-4 \\
\text { (Otolith) }\end{array}$ & - & $\mathrm{TL}$ & 13 & 41.7 & 3.38 & - & - & - & - & - \\
\hline \multirow{3}{*}{ Cengiz (2012) } & \multirow{3}{*}{$\begin{array}{c}\text { Saros Bay by } \\
\text { Gill net- } \\
\text { Handline- } \\
\text { Purse seine } \\
\end{array}$} & \multirow{3}{*}{$\begin{array}{c}1-5 \Sigma \\
\text { (Otolith) }\end{array}$} & $\Sigma$ & $\mathrm{TL}$ & 13.8 & 31.1 & 3.1 & 0.96 & 39 & 0.2 & -2.13 & 2.48 \\
\hline & & & 9 & $\mathrm{TL}$ & 13.8 & 31.1 & 3.12 & 0.97 & 37.3 & 0.22 & -1.93 & 2.49 \\
\hline & & & 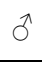 & $\mathrm{TL}$ & 15.1 & 30.8 & 3.08 & 0.96 & 41.4 & 0.17 & -2.37 & 2.46 \\
\hline \multirow{3}{*}{$\begin{array}{l}\text { Allaya et al. } \\
\text { (2013) }\end{array}$} & \multirow{3}{*}{$\begin{array}{c}\text { Tunisian Sea } \\
\text { by } \\
\text { purse seine, } \\
\text { light fishing, } \\
\text { gill nets, } \\
\text { longlines, } \\
\text { pelagic trawl } \\
\text { and beach } \\
\text { seine). }\end{array}$} & \multirow{3}{*}{-} & $\Sigma$ & FL & 16.3 & 31.8 & 3.02 & 0.96 & - & - & - & - \\
\hline & & & $q$ & FL & 17 & 31.8 & 2.99 & 0.97 & - & - & - & - \\
\hline & & & $\hat{\sigma}$ & FL & 16.3 & 27.3 & 3.07 & 0.96 & - & - & - & - \\
\hline $\begin{array}{l}\text { Samuel et al. } \\
\text { (2016) }\end{array}$ & $\begin{array}{c}\text { Eastern } \\
\text { coastline of } \\
\text { Ghana by } \\
\text { multifilament } \\
\text { fishing gears. }\end{array}$ & - & $\Sigma$ & - & - & - & - & - & 26.78 & 1.3 & -0.13 & 2.97 \\
\hline $\begin{array}{l}\text { Jurado-Ruzafa } \\
\text { et al. }(2017)\end{array}$ & $\begin{array}{l}\text { NE Atlantic } \\
\text { By trawl }\end{array}$ & $\begin{array}{c}0 \text { to } 7 \\
\text { (Otolith) }\end{array}$ & - & $\mathrm{TL}$ & 12.4 & 49 & 3.46 & - & - & - & - & - \\
\hline Daley (2018) & NW Atlantic & $0-7$ & - & $\mathrm{TL}$ & 17.7 & 39.7 & 2.72 & - & 33.56 & 1.75 & 0.07 & - \\
\hline
\end{tabular}


(Otolith)

Alex. Coast,

Medi. Sea,

Present study

Egypt.

By night

1 to $5 \Sigma$

purse seine

(L. frequency)

\begin{tabular}{|c|c|c|c|c|c|c|c|c|c|}
\hline \multirow{3}{*}{$\Sigma$} & TL & 12.9 & 34.4 & 3.15 & 0.98 & 38.11 & 0.186 & - & 2.68 \\
\hline & FL & 11.8 & 31.5 & 3.23 & 0.99 & - & - & - & - \\
\hline & SL & 10.9 & 29.4 & 3.19 & 0.98 & - & - & - & - \\
\hline \multirow{3}{*}{ 우 } & $\mathrm{TL}$ & 18.6 & 34.4 & 3.24 & 0.96 & - & - & - & - \\
\hline & FL & 17 & 31.5 & 3.21 & 0.98 & - & - & - & - \\
\hline & SL & 15.7 & 29.4 & 3.27 & 0.95 & - & - & - & - \\
\hline \multirow{3}{*}{ o } & TL & 18.6 & 32.6 & 3.25 & 0.98 & - & - & - & - \\
\hline & FL & 17 & 29.8 & 3.12 & 0.98 & - & - & - & - \\
\hline & SL & 15.7 & 27.4 & 3.34 & 0.97 & - & - & - & - \\
\hline
\end{tabular}

Table 5. The mean absolute and relative conditions of genus Scomber from various locations.

\begin{tabular}{|c|c|c|c|c|}
\hline References & Area & Sex & $\mathrm{Kc}$ & $\mathrm{Kn}$ \\
\hline \multirow{3}{*}{$\begin{array}{l}\text { Ghailen et al. } \\
\text { (2010) }\end{array}$} & \multirow{3}{*}{$\begin{array}{c}\text { Gulf of Gabes } \\
\text { (Southern Tunisia, } \\
\text { Central } \\
\text { Mediterranean) }\end{array}$} & $\Sigma$ & $0.92 \pm 0.24$ & ------ \\
\hline & & q & $0.93 \pm 0.65$ & ----- \\
\hline & & $\delta$ & $0.87 \pm 0.45$ & - \\
\hline \multirow{2}{*}{ Allaya et al. (2013) } & \multirow{2}{*}{$\begin{array}{c}\text { Tunisian waters } \\
\text { Mediterranean Sea) }\end{array}$} & $q$ & 1.15 & - \\
\hline & & 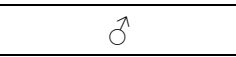 & 1.2 & ------ \\
\hline \multirow{3}{*}{$\begin{array}{l}\text { Bal and Türker, } \\
\text { (2019) }\end{array}$} & \multirow{3}{*}{ Sea of Marmara } & $\Sigma$ & $0.95 \pm 0.09$ & ------- \\
\hline & & $q$ & $0.94 \pm 0.11$ & $\begin{array}{l}------ \\
\end{array}$ \\
\hline & & $\hat{0}$ & $0.91 \pm 0.10$ & -------- \\
\hline \multirow{6}{*}{$\begin{array}{l}\text { Langøy, et al., } \\
\text { (2012) }\end{array}$} & \multirow{6}{*}{$\begin{array}{c}\text { Water masses in the } \\
\text { Norwegian Sea }\end{array}$} & $\Sigma 2004$ Arctic & ----------- & $1.03 \pm 0.09$ \\
\hline & & $\Sigma 2004$ Atlantic & --------- & $1.00 \pm 010$ \\
\hline & & $\Sigma 2004$ Coastal & - & $0.99 \pm 0.10$ \\
\hline & & $\Sigma 2006$ Arctic & - & $0.96 \pm 0.08$ \\
\hline & & $\Sigma 2006$ Atlantic & 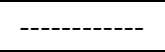 & $1.00 \pm 0.08$ \\
\hline & & $\Sigma 2006$ Coastal & --------- & $0.81 \pm 0.08$ \\
\hline \multirow{3}{*}{$\begin{array}{c}\text { Jurado-Ruzafa } e t \\
a l,(2016)\end{array}$} & \multirow{3}{*}{$\begin{array}{c}\text { Canary Islands (NE } \\
\text { Atlantic, Spain) }\end{array}$} & $\Sigma 2013$ & --------- & 1.003 \\
\hline & & $\sum 2014$ & --------- & 1.021 \\
\hline & & $\Sigma 2015$ & -------- & 1.006 \\
\hline \multirow{3}{*}{ This study } & \multirow{3}{*}{$\begin{array}{l}\text { Alex. Coast, Medi. } \\
\text { Sea, Egypt. }\end{array}$} & $\Sigma$ & $0.89 \pm 0.06$ & $1.01 \pm 0.08$ \\
\hline & & q & $0.72 \pm 0.05$ & $0.82 \pm 0.05$ \\
\hline & & 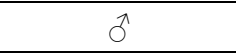 & $0.73 \pm 0.05$ & $0.82 \pm 0.05$ \\
\hline
\end{tabular}




\section{CONCLUSION}

In conclusion, data on age and growth of chub mackerel fish $S$. japonicus from the Egyptian Mediterranean water showed a positive allometric mode of growth and good condition indices. Furthermore, the estimated age and expected maximum length reflected suitability of habitats of this important species. Monitoring the fishery should be performed for further management.

\section{REFERENCES.}

Aguayo, M. and Steffens, H. (1986). Edad y crecimiento de Somber japonicus del norte de Chile. Invest. Pesq., 33: 61-76.

Akel, E. H. Kh. (2009). Fisheries of experimental purse seine net using light and population dynamics of Sardinella aurita (Family clupeidae) east of Alexandria, Egypt. Egypt. J. Aquat. Boil. \& Fish.,13 (1): 55-77.

Allaya, H.; Hattour, A.; Hajjej, G.; and Trabelsi, M. (2013). Biologic characteristics of Scomber japonicus (Houttuyn, 1782) in Tunisian waters (Central Mediterranean Sea). Afri. J. Biotech., 12 (20): 3040- 3048.

Bagenal, T. B. and Tesch, F. W. (1978). Age and growth. In methods for the assessment of fish production in freshwaters (Ed. T.B. Bagenal) 3rd ed. I. B. P. Handbook, Blackwell, Oxford, pp. 93-130.

Bal, H. and Türker, D. (2019). Investigation Some Biological Properties of Atlantic Mackerel Scomber scombrus Linnaeus,1758 in the Sea of Marmara. NE Scie.,4 (2) :133-1401758.

Bayhan, B. (2007). Growth characteristics of the Chub Mackerel (S.japonicus Houttuyn, 1782) in Izmir Bay. J. Anim. Vet. Adv., 6 (5): 627-634.

Beverton, R. J. H. and Holt, S. J. (1957). On the dynamics of exploited fish population. U. K. Min. Agr. Fish. Invest. Ser., 19:533p.

Bhattacharya, C. G. (1967). A simple method of resolution of a distribution into Gaussian components. Biomet., 23 (1): 115-135.

Campana, S. E. (2001). Review: Accuracy, precision and quality in age determination, includes a review of the use and abuse of age validation methods. J. Fish Biol., 59: 197-242.

Carvalho, N.; Perrotta, R.G. and Isidro, E. (2002). Age, growth and maturity in chub mackerel (Scomber japonicus Houttuyn, 1782) from the Azores. Arquipélago Ciências Biol. Mari., 19: 93- 99. http://hdl.handle.net/10400.3/169 
Castro, J. J. and Santana, A. T. (2000). Synopsis of biological data on the chub mackerel (Scomber japonicus Houttuyn, 1782). FAO Fish. Synopsis $\mathrm{N}^{\circ}$ $157: 77 \mathrm{pp}$.

Cengiz C. (2012). Age, Growth, Mortality and Reproduction of the Chub Mackerel (S.japonicus Houttuyn, 1782) from Saros Bay (Northern Aegean Sea, Turkey). Turk. J. Fish. Aquatic Sci., 12: 799-809. DOI: 10.4194/13032712-v12_4_08.

Collette, B. B. and Nauen, C. E. (1983). FAO species catalogue. Vol. 2. Scombrids of the world. An annotated and illustrated catalogue of tunas, mackerels, bonitos and related species known to date. FAO Fish. Synop., (125) Vol. 2: 137 p.

Daley, T. T. (2018). Growth and reproduction of atlantic chub mackerel (Scomber colias) in the Northwest Alantic. M.Sc. Thesis, College of Sci. \& Technol. $\&$ the School Ocean Sci., Univ. South. Mississippi., 364 pp.

El - Aiatt, A. A. O. and Shalloof, K. A. Sh. (2020). Reproductive biology of the Atlantic mackerel Scomber scombrus Linnaeus, 1758 in Mediterranean coast of Sinai, Egypt. Egypt. J. Aquat. Biol. Fish., 24(1): 189 - 201.

El-Okda, N. A. M. (1998). Comparative studies on Certain Biological Aspects of Siganus in Marine waters of Egypt. Ph.D. Thesis, Zagazig Univ., Egypt.

F.A.O (2010). FAO annual yearbook. Fishery and Aquaculture Statistics. 2008. http://www.fao.org/docrep/013/i1890t/i1890t.pdf (accessed on 10 May 2010).

Faltas, S. N. (1983). Study of purse-seine fisheries in Egyptian Mediterranean waters with special reference to the biology of sardine in the catch. M. Sc. Thesis, Fac. Sci, Alex. Univ. 194 pp.

Faltas, S. N. and Rizkalla, S. I. (1995). Biometeric comparison of chub mackerel (Scomber japonicus Houttuyan, 1782) from the Mediterranean and Red Sea, Egypt Bull. Nat. Inst. Oceanogr. \& Fish. A.R.E., 2 (21): 439-449.

Farrag, M. M. S.; Osman , A. G. O.; Akel, E.H. Kh and Moustafa, M. A. (2014). Catch and effort of night purse seine with emphasize to Age and Growth of lessepsian Etrumeus teres (Dekay, 1842), Mediterranean Sea, Egypt. Egypt J. Aquat. Res., 40: 181-190.

GAFRD, General Authority for Fish Resources Development (2018). Annual reports of fish statistics, Cairo, Egypt.

Gang, L.; Xinjun, C. and Feng, B. (2008). Age and growth of chub mackerel (S.japonicus) in the East China and Yellow Seas using sectioned otolith 
samples. J. Ocean Univ. Chin., 7 (4): 439-446. Doi: 10.1007/s11802-0080439-9.

Gayanilo, F. C.; Sparre, P. and Pauly, D. (1997). FAO-ICLARM stock assessment tools. Reference manual.ICLARM International Center for Living Aquatic Resources Management Food and Agri. Organiz. Unit. Nation. Rome., PP 262.

Ghailen, H.; Abdallah, H.; Hassan, A.; Mourad, C.; Abderrahmen, B. and Othman, J. (2010). Length-weight relationships for 13 fish species from the Gulf of Gabes (Southern Tunisia, Central Mediterranean). Afri. J. Biotechnol., 9 (37): 6177-6181.

Gluyas-Millan, M. G. and Quinonez-Velazquez, C. (1997). Age, growth, and reproduction of Pacific mackerel Scomber japonicus in the Gulf of California. Bull. Mar. Sci. Miami, 61 (3): 837-847.

Hwang, S.; Kim, J. and Lee, T. (2008). Age, growth, and maturity of Chub Mackerel off Korea. N. Amr. J. Fish. Manage., 28 (5): 1414-1425. Doi: 10.1577/M07-063.1.

İşmen, A.; Özen, Ö.; Altınağaç, U.; Özekinci, U. and Ayaz, A. (2007). Weightlength relationships of 63 fish species in Saros Bay, Turkey. J. Appl. Ichthyol., 23: 707-708. Doi: 10.1111/j.1439-0426.2007.00872.

Jurado-Ruzafa, A.; Bartolomé, A.; Carrasco, N. and Duque-Nogal, V. (2016). Relaciones talla-peso de los pequeños peces pelágicos más capturados de las islas Canarias (Atlántico NE, España). Vieraea, 44: 107-116.

Jurado-Ruzafa, A.; Hernández, E. and M Teresa G. Santamaria (2017). Edad, crecimiento y mortalidad natural de la caballa Scomber colias (Perciformes: Scombridae) de Mauritania (NO África). Vieraea, 45: 53-64.

Karakulak, F. S.; Erk, H. and Bilgin, B. (2006). Length-weight relationships for 47 coastal fish species from the northern Aegean Sea, Turkey. J. Appl. Ichthyol., 22: 274-278. Doi: 10.1111/j.1439-0426.2006.00736.

Kiparissis, S.; Tserpes, G. and Tsimenidis, N. (2000). Aspects on the demography of Chub Mackerel (S.japonicus Houltuyn, 1782) in the Hellenic Seas. Belg. J. Zool., 130 (1): 3-7.

Krivospitchenko, S.G. (1979). Mackerel (S.japonicus) of the Saharan littoral region. Meeting of the Ad Hoc Working Group on West African Coastal Pelagic Fish from Mauritania to Liberia (26 gr N to 5 gr N), Dakar (Senegal), 19 Jun 1978, FAO Fisheries Department, Rome: 125-128.

Lagler, K. F. (1956). Fresh water fishery biology. (W. M. C., Browned) Comp, Dubuque, Iowa, $421 \mathrm{pp}$. 
Langøy, H.; Nøttestad, L.; Skaret, G.; Broms, C. and Fernö, A. (2012). Overlap in distribution and diets of Atlantic mackerel (Scomber scombrus), Norwegian spring-spawning herring (Clupeaharengus) and blue whiting (Micromesistiuspoutassou) in the Norwegian Sea during late summer. Mar. Biol. Res., 8:5-6, 442-460. DOI: 10.1080/17451000.2011.642803.

Le-Cern, E. D. (1951). The length-weight relationship and seasonal cycle ingonad weight and condition in perch Perca fluviatilis. J. Animal Ecol., 20 (2): 201-219.

Lorenzo, J. M.; Pajuelo, J. G. and Ramos, A. G. (1995). Growth of chub mackerel Scomber japonicus (Pisces: Scombridae) off the Canary Islands. Sciemtoa Mar., 59 (3.4): 287-291.

Martins, M.M. and Serrano-Gordo, L. (1984). On the comparison of spanish mackerel (S.japonicus Houltuyn, 1782) from Gorringe Bank and Peniche. ICES, $14 \mathrm{pp}$.

Mehanna, S. F. (2002). Fisheries management of the slimy mackerel Scomber japonicus in the Gulf of Suez based on relative yield per recruit analysis. Egyp. J. Aquat. Biol. Fish., 6 (3): 217-232.

Mehanna, S. F. (2004). Maximum sustainable yield of the round herring, Etrumeus teres, and slimy mackerel, Scomber japonicus in the Gulf of Suez, Egypt. J. Aquat. Res., 30 (B): 322-325.

Mendes, B.; Fonseca, P. and Campos, A. (2004). Weight-length relationships for 46 fish species of the Portuguese west coast. J. Appl. Ichthyol., 20: 355361. Doi: 10.1111/j.1439-0426.2004.00559.

Mendo, J. (1984). Edad, crecimiento y algunos aspectos reproductivos y alimentarios de la caballa $S$. japonicus peruanus. Bol. Inst. Mar PerCallao., 8: 101-156.

Ndimele, P. E.; Kumolu-Johnson, C. A.; Aladetohun, N. F. and Ayorinde, O. A. (2010). Length-weight relationship, condition factor and dietary composition of Sarotherodon melanotheron, Ruppell, 1852 (Pisces: Cichlidae) in Ologe Lagoon, Lagos, Nigeria. Agri. Biol. J. N. Amer., 1: 584-590.

Ouchi, A. (1978). Studies on the age and growth of common mackerel Scomber japonicus, in the waters West of Kyushu and East of Tsushima Islands. Bull. SeikaiReg. Fish. Res. Lab., (51): 97-98.

Özaydın, O. and Taşkavak, E. (2006). Length-weight relationships for 47 fish species from Izmir Bay (eastern Aegean Sea, Turkey). Acta Adriat., 47(2): 211-216. 
Pauly, D. (1983). Some simple methods for assessment of tropical fish stocks. FAO Fisheries Technical Paper, Rome, pp. 52-234.

Pauly, D. and Munro, J. L. (1984). Once more on the comparison of growth in fish and invertebrates. International Center for Living Aquatic Resources Management (ICLARM), Fish byte, 2(1): 21.

Perrotta, R. G.; Carvalho, N. and Isidro, E. (2005). Comparative Sudy on Growth of ChubMackerel (S. japonicus Houttuyn, 1782) From Three Different Regions: NWMediterranean, NE and SW Atlantic. Rev. Invest. Desarr. Pesq. No 17: 67-79 .

Perrotta, R. G. (1992). Growth of mackerel (S. japonicus Houltuyn, 1782) from the Buenos Aires-north Patagonia Region (Argentine Sea). Sci. Mar., 56 (1): 7-16.

Richter, H. C.; Luckstadt, C.; Focken, U. and Becker, K. (2000). An improved procedure to assess fish condition on the basis of lengthweight relationships. Arch. Fish. Mar. Res., 48: 255-264.

Ricker, W. E. (1973). Linear regression in fisheries research. J. Fish. Res. Board Can., 30: 409-434.

Rizkalla, S. I. (1998). Some biological characters of Chub Mackerel (Scomber japonicus, Houttuyan, 1782) from the Mediterranean warwes of Egypt. Egypt. J. Aquat. Biol. Fish., 2 (2), 201 -116.

Rizkalla, S. I. and Faltas, S. N. (1997). Feeding Habits of Chub Mackerel (Scomber japonicus) in Egyptian Mediterranean. J. king Abdulaziz Univ. Mar. Sci., 8: 127- 136.

Robinson, M. P. and Motta, P. J. (2002). Patterns of growth and the effects of scale on the feeding kinematics of the nurse shark (Ginglymostoma cirratum). J. Zool., Lond, 256:449-462.

Samat, A.; Shukor, M. N.; Mazlan, A. G.; Arshad, A. and Fatimah, M. Y. (2008). Length-weight Relationship and Condition Factor of Pterygoplichthys pardalis (Pisces: Loricariidae) in Malaysia Peninsula. Res. J. Fish. Hydrobiol., 3 (2): 48-53.

Santos, M.; Gaspar, M.; Vasconcelos, P. and Monteiro, C. (2002). Weightlength relationships for 50 selected fish species of the Algarve coast (southern Portugal). Fish. Res.. 59 (1): 289-295.

Sinovčić, G.; Franičević, M.; Zorica B., and Cikeš Keč, V. (2004). Lengthweight and length-length relationships for 10 pelagic fish species from the Adriatic Sea (Croatia). J. Appl. Ichthyol., 20: 156-158. Doi: 10.1046/j.1439-0426.2003.00519. 
Statistica (2007). Statsoft-Inc for Windows Release, U.S.A.

Tuggac, M. (1957). On the biology of the Scomber colias Gmelin. Gener. Fish. Counc. Medit. (GFCM), 4:145-159.

Vasconcelos, J.; Dias, M. A. and Faria, G. (2011). Age and growth of the Atlantic chub mackerel Scomber colias Gmelin, 1789 off Madeira Island. Revista de Biol. Mar. Oceano., 1:27-34.

Weatherly, A. H. and Gill, H. S. (1987). The biology of fish growth, London, academic Press, pp.433-443. 